\title{
Az Állattani Szakosztály ülései (2017. február 8. - 2017. november 8.)
}

\author{
TÓTH BALÁZS \\ Magyar Természettudományi Múzeum Állattára, 1088 Budapest, Baross u. 13. \\ *E-mail: toth.balazs@nhmus.hu
}

\section{7. előadóülés, 2017. február 8-án}

Az ülés levezető elnöke NAGY PÉTER, annak megnyitása után beszámolt a jegyzőváltásról, mely MECSNÓBER MELINDA hathatós segítségével zajlott.

1. SCHNEIDER ZOLTÁN és SzÖVÉNYI GERGELY: Egyenesszárnyú rovar együttesek tér-és idöbeli változásai a Tétényi-fennsik TT gyeprekonstrukciós területén.

Az előadást SCHNEIDER Z. biológus MSc hallgató tartotta, akinek ez volt az első előadása a Szakosztályban. A kutatási terület a Mechanikai Müvek-Diósd-Törökbálint által határolt területe, mely korábban szovjet katonai lőtér volt, jelenleg pedig országos jelentőségü védelem alatt áll. Uralkodóan száraz gyep, ám a területen az 1990-es évek (legelés megszünése) óta szukcesszió zajlik (galagonyával cserjésedik), ill. gyomosodik. Jelenleg a Duna-Ipoly Nemzeti Park kezeli LIFE-pályázat keretében, és gyeprekonstrukciót is végrehajtanak rajta. A galagonyát kézi erővel irtják, gépekkel elszállítják, ezen kívül a hulladékot is elviszik (a kommunális- és ipari hulladék egyaránt sok a területen). Célokként az alapállapot felvételét, majd a gyeprekonstrukció hatásának vizsgálatát tüzték ki. A vizsgált csoport kiválasztását az indokolta, hogy az Orthoptera rend fajai jelentős táplálékbázisként játszanak szerepet a táplálékhálózatban, jól határozhatók, és védett fajok is vannak köztük. A területen négy főbb élőhelytípust különböztettek meg, úm. 1. nem cserjésedő lejtősztyep, 2. cserjésedő lejtősztyep, 3. ruderális terület $100 \%$ alatti borítottsággal, és 4 . teljesen kopár talajfelszín. 2014-2016 folyamán július és szeptember hónapokban végeztek mintavételt (300 fúhálócsapás, valamint egyelés a nehezen fúhálózható fajokra) 41 mintavételi ponton. Az alapállapot felmérésénél ordinációs módszerrel azt az eredményt kapták, hogy a nemcserjésedőés a cserjésedő gyep, valamint a degradált és a kopár terület csoportosulnak együtt, a klaszteranalízis szerint pedig a nemcserjésedő- és a cserjésedő gyep voltak testvércsoportok, amiknek testvércsoportja a kopár terület, míg a degradált gyep mindegyik másik területtípussal (de főleg a kopárral) keverten jelent meg az elemzésben. Fajkészlet tekintetében a degradált területen volt a legtöbb faj - valószínüleg a sokféle mikrohabitat miatt - és az Acrida ungarica faj is túlnyomórészt itt fordult elő. Időbeli változást nézve ordinációval a kopár elkülönül, a másik három területtípus pedig összefolyik; föleg a Glyptobothrus mollis faj miatt. Az abundancia a kopár terület kivételével mindenhol növekedett 2015-2016 között. A gyeprekonstrukció hatásait négy mintavételi pontban vizsgálták, az abundancia 
ezeknél nőtt, ám a fajszám nem. Összegzésként Előadó elmondta, hogy az eltérő növényzetủ foltokon eltérő közösségek laknak, de a gyeprekonstrukció hatása így is mindenütt pozitív. NAGY PÉTER: Miért volt az Acrida ungarica föként degradált helyeken? SCHNEIDER ZOLTÁN: Talán azért, mert a közepes bolygatottság nagy diverzitást tart fenn. NAGY PÉTER: Meddig szeretnék folytatni a vizsgálatokat? SCHNEIDER ZOLTÁN: A LIFE-pályázat 2018-ig szól, ám utána is jó lenne folytatni. NAGY PÉTER ezután sok sikert kívánt. Dr JÁNOSSY LÁsZLó (a kérdés feltevése előtt elmondta magáról, hogy a Herman Ottó Intézetben dolgozott annak megszünéséig, azután a Klímakutató Központba került): Vizsgálták-e, hogy az utolsó stádiumú lárvák mikor alakulnak át imágóvá, és hogy ez az időpont változott-e a korábbi évekhez képest? Saját megfigyelése alapján a mezei tücsök egy hónappal korábban kezd ciripelni (alakul át), mint régebben. SCHNEIDER ZOLTÁN: Ilyen vizsgálatot ők nem végeztek. SZÖVÉNYI GERGELY: Léteznek ilyen vizsgálatok, NAGY BARNABÁS sok megfigyelést tett a témában, melyekről egy cikk írása folyamatban van. Masszív kapcsolat van a kelési idő és a klíma között. A júliusi mintavételt úgy állapították meg, hogy a legtöbb faj már imágó alakban legyen, és a korán végződő rajzásidővel bíró fajok is még beleessenek a mintába.

\section{PÉNTEK ATTILA LÁsZló: Jellemzö kétéltü közösségek elöfordulása Magyarországon.}

A vizsgálat célja az együttes előfordulások vizsgálata volt. Alapadatbázisként a Magyar Madártani Egyesület „herptérkép”-ébe felvitt adatok szolgáltak. Közösségi adatbevitel történik ("citizen science"), önkéntesek, természetvédelmi szakemberek, ill. természetjáró laikusok által. Az adatokat szürik, a laikusok adatait csak fényképpel alátámasztva fogadják el. 2016 végéig 13613 adat gyült össze, legtöbbjük az erdei békáról, legkevesebb az alpesi tarajosgőtéről. Az ország 10×10 km-es UTM négyzetein belüli együtt-előfordulást vizsgálták. 12 volt a legnagyobb fajszám ugyanabban a négyzetben; a Mátra, a Zemplén és az Örség területén voltak ilyenek. A co-occurrence mátrix azt mutatta, hogy a legtöbb fajpár a véletlennél nagyobb mértékben fordul elő. Negatív kapcsolat is kijöhetett volna elvileg, de a négyzetrács túl nagy volt, nem volt elég finom a felbontás. Öt fajnál találták, hogy országszerte igen elterjedt. Jellemző közösségeknek a következők bizonyultak: 1. Triturus alpestris hegyi fajokkal (pl. B. variegata, S. salamandra) való előfordulása; 2. Bombina variegata fajnál az előzőhöz hasonló területi eloszlás, ám több négyzetben, és hasonló fajösszetételekben, de a $B$. bufo és $R$. dalmatina fajokkal több helyen együtt, mint az elöbbi csoportnál; 3. Rana arvalis faj esetében sok alföldi adat, ahol $H$. arborea, B. bombina, $B$. bufo és $R$. dalmatina fajokkal együtt található, míg hegyi fajok ezen négyzetekben alig voltak. Egy átlagos négyzetben 10 fajra lehet számítani. Az országnak vannak gyéren kutatott területei. NAGY PÉTER: Az adatelemzés lehet-e eszköz arra, hogy a potenciális és megfigyelt fajösszetételek közötti különbségek alapján minősítsük az élöhelyeket? PÉNTEK ATTILA LÁszLó: Lehet, de ez élőhelyfüggő. NAGY PÉTER: Lehet-e az alig feltárt helyekre predikciókat tenni, majd a tényleges fajkészlettel összehasonlítani, értékelni a predikciót? PÉNTEK ATTILA LÁSZló: Lehet, de a feltáratlan területek nagy része mezögazdasági. JÁNOSSY LÁSZLÓ: Mezőgazdasági területeken lehet-e vizsgálni a peszticidek hatását? Például Bugyi mellett, saját tapasztalta szerint peszticid alkalmazása után eltünt a $B$. bombina. PÉNTEK ATTILA LÁSZLÓ: Tudtával ilyen vizsgálat még nem zajlott. JÁNOSSY LÁSZLÓ: Békamentéseken gyüjtött adatok (faj- és egyedszám) feldolgozása alapján nyert eredményeiket megírták a "Magyarország környezeti állapota 2015" c. kiadványban, mely hamarosan megjelenik. PÉNTEK ATTILA LÁsZLó: Látszik-e csökkenés? JÁNOSSY LÁSZLÓ: Néhol lát- 
szik, máshol kevés az adat. Nézték, hogy összefügg-e a csapadékkal vagy az időjárással, de nem. Pedig elvileg kellene legyen ilyen összefüggés. PÉNTEK ATTILA LÁszLó a TolnaBaranyai-dombságban helyi összefüggést talált: a 2012-es száraz évben kevesebb volt a fajés egyedszám is, mint máskor.

3. SZÖVÉNYI GERGELY és KLEIN ÁKOs: A montado öszi arca - egy portugáliai Erasmus gyakorlatról zoológus szemmel.

Hat szervezet vett részt egy projektben, mely természetvédelmi életpályához nyújt segítséget, információt, muníciót az egyetemet frissen végzett hallgatók számára. E projekt keretében ötnapos hallgatói tréninget rendeztek Portugáliában, melyen három ország hallgatói vettek részt. A helyszín Evora városának az egyeteme volt, melynek épületei szétszórva találhatók a városban, ill. attól kb. 10 km-re, egyetemi tulajdonban lévő sokhektáros területen, melynek nagy részén a montado az uralkodó növényzet. A montado egyfajta fás legelő, melyet néhány ezer éve alakítottak ki tölgyerdők helyén úgy, hogy a paratölgy egyedeket meghagyták, az egyéb fákat pedig kisebb-nagyobb mértékben eltávolították. A montadóban paragyüjtést és makkoltatást folytattak. A használat intenzitásától függően létezik nyílt, bozótos, ligetszerủ és szinte teljesen zárt változata, melyeket mind képekben is bemutatott az Elöadó. Az egyetemnek sok részlege 400 éves épületekben müködik, ami különleges hangulatot kölcsönöz. A környéken ókori és középkori vízvezetékek sürü hálózata található, ugyanis sok kertgazdaság volt régen a környéken, és van ma is. A hallgatói foglalkozások reggel kezdődtek a tantermekben, kis csoportokban dolgoztak, gyakran Skypekonferenciával egybekötve. Ebédszünet után biodiverzitási gyakorlati feladatokat hajtottak végre terepi kirándulásokon, majd a tantermi foglalkozások folytatódtak, gyakran egészen 21:00-ig. Ezután szabadidő következett, melyet az Előadók esti sétákkal, a montado élővilágának további megfigyelésével töltöttek. Sok képet láthattunk helyi állatokról, főleg egyenesszárnyúakról és kétéltűekről. A környéken őshonos a nálunk állateledelként árult kétfoltos tücsök, sok a különféle gekkó, és a nyugati ásóbéka is előfordul. Az egyetemi területen a montadót már nem legeltetik, így az valószínúleg fajgazdagabb, mint máshol. Viszont másféle beavatkozásra sajnos van esély: az egyetem oktatói mutattak egy szerkezetet, amellyel - állítólag - még az idős, terebélyes paratölgy egyedeket is sikeresen át lehet ültetni. A városban megtartott foglalkozások szüneteiben az előadóknak alkalmuk nyílt a középkori városmagot bejárni. Itt többek között egy ókori Diana-templom is látható. Látogatásuk alatt érkezett meg az ősz első esője, mely újabb állatokat csalogatott elő. Az előadók nagyon örültek egy rikítózöld színü, szépen mintázott gőtének (Triturus pygmaeus), de megfigyelhettek még legalább három imádkozósáska-fajt, többféle varangyot, korongnyelvü békát, endemikus szöcskefajokat, rovarpókot és a maggyüjtő hangyák tömegrajzását is. Egy vízmosásban elpusztult márványrákot találtak, mely betelepült faj, ám a helyi ragadozók fogyasztják. Talán a legfontosabb megfigyelésük a szürke féreggyík egy példánya volt. Ez a földalatti életmódot folytató hüllő igen ritka, nagyon kevés adata volt a környékről. A hazafelé úton a repülőgép indulására várva Lisszabonban is volt alkalmuk sétálni, ám a ködös idő miatt nem élvezhették a város teljes szépségét. TóTH MÁRIA örömét fejezte ki, hogy az előadók eljutottak Portugáliába, ugyanis az az ország benne is mély nyomokat hagyott. Megkérdezte, hogy mik a további tervek a projekttel kapcsolatban. SzÖVÉNYI GERGELY: Ez a projekt egy tananyag tesztelésére szolgál, és még két ilyen alkalmat fognak rendezni (Magyarországon és Nagy-Britanniában egyet-egyet). A Gyöngybagoly Alapítvány honlapján megtekinthető, interaktív formában. Távlati cél a dolog hosszútávú fenntartása. 
Az előadóülés végén meg lehetett tekinteni az Állattani Közlemények 2016. évi kötetének egy példányát.

\section{8. előadóülés, 2017. március 1-én}

Az ülést NAGY PÉTER elnök úr vezette le.

1. SZÖVÉNYI GERGELY és PUSKÁS GELLÉRT: Az egyenesszárnyú rovarok európai vörös listája - általános áttekintés és magyar vonatkozások.

Munkájukat az IUCN keretén belül végezték. A kutatásról megjelent egy kiadvány, melyet papíralapon körbeadott az Előadó az ülés résztvevőinek, de az IUCN honlapjáról ugyanez pdf formátumban letölthető. 1082 fajt tartalmaz, ebből 7 nem őshonos Európában. A vizsgálandó fajok köréböl kizárták a problematikus taxonokat. Minden faj értékelése különkülön publikációnak számít, ennek megfelelően újabban DOI kódot is kapnak, és a Web of Science is listázza őket. A legtöbb élölénycsoportban a fajok zömének állománytrendje ismeretlen, a természetvédelmi kategóriák közül a CR, EN és VU kategóriákba tartozik az összes faj negyede. Ebben a kutatásban a fajgazdagság területi eloszlását korábban nem látott pontosságban ábrázolták. A hazai védett fajok közül négynek az európai állománya jelentős része hazánkban él, így pl. a törös szöcske állományának 1/3-a nálunk található, a keleti pókszöcske pedig Európában csak a Kárpát-medencében honos. JÁNOSSY LÁSZLÓ: Nézték, hogy a nálunk védett fajok regionális vörös listán szerepelnek-e? SzÖVÉNYI GERGELY: A magyar védettség jól egybevág a hazai populációk veszélyeztetettségével, ám az európai veszélyeztetettséggel nem mindig (pl. hegyvidéki fajoknál).

2. Bukor boglárka, BóKony Veronika, Hammer tamás, Papp SÁndor, Pipoly

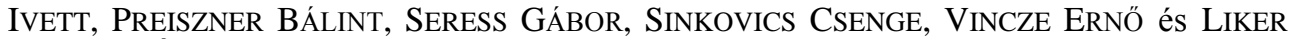
ANDRÁs: Éven belüli és évek közötti újrafészkelés gyakorisága erdei és városi széncinege populációkban.

Előadó, BUKOR BOGLÁRKA korábban még nem tartott előadást a Szakosztályban. A kutatási téma azért aktuális, mert a városok területe világszerte erősen növekszik, ugyanakkor ezek és a természetes területek között sok különbség figyelhető meg a biotikus (pl. kevesebb rovartáplálék) és az abiotikus tényezőkben (pl. hőmérséklet) egyaránt. Ennek megfelelően a városi madárpopulációk fészkelési szezonja korábban indul, fészekaljuk kisebb, ugyanakkor denzitásuk nagyobb, mint a természetes élőhelyeken élő állományoké - ez utóbbinak oka az újraköltések eltérő száma lehet. Szerzők kíváncsiak voltak arra, hogy a városi madarak egy éven belül többször költenek-e, a vizsgált évek során több fészekaljat raktak-e, és több fiókát röptettek-e ki, mint természetközeli fajtársaik. Két városi és két erdei területen helyeztek ki odúkat, négy éven át vizsgálták a költéseket. Minden odút kamerával figyeltek, minden költő madarat és fiókát gyürüztek. Az adatokból a következő változókat számolták: egy-egy tojó éven belüli és évek közötti újrafészkelése, összes költésének száma, összes fiókájának száma, valamint fészekhüsége éven belül és évek között (ugyanabban az odúban fészkelt-e egymás után). Szerzők a következő eredményeket kapták: az azonos éven belüli újraköltések számában nincs különbség a kétféle élőhely között; az első költések száma minden évben nőtt, de a másodköltéseké fluktuált; az évek közötti újraköltések számában nem volt szignifikáns különbség város és erdő között; városban még nyolc- 
szor költő tojó is előfordult, de az erdőn legfeljebb hatszor költött egy-egy madár; az erdőben másfélszer annyi fióka repült ki összesen, mint a városban - ez a különbség nagynak számít, mert magas a fiókák mortalitása; a fészekhüség becslésénél arra jutottak, hogy az éven belüli hüség az erdei példányoknál sokkal nagyobb, mint a városiaknál, míg az évek közötti fészekhüség esetén éppen fordított a helyzet. Az eredményekből az alábbi következtetéseket vonták le: a városi széncinegék nagyobb denzitását az erdeiekhez képest a jobb túlélés vagy a környékről történő bevándorlás magyarázhatja, mivel a költések száma nem nagyobb; a cinegék másodköltéshez szívesebben használnak üres odút, ha rendelkezésre áll; az örvös légykapók abban az időben költenek elöször, amikor a cinegék már másodszor. Az előadáshoz SZIRÁKI GYÖRGY megjegyzést füzött: Város és város, ill. park és park között is vannak különbségek. Előadó erre úgy reagált, hogy ilyen témájú kutatásokat még nem végeztek, nincs tapasztalatuk. SzIRÁKI GYÖRGY: Feltételezéssel éltek más adatok alapján, de más városban talán más eredményeket kaptak volna. BUKOR BOGLÁRKA: Hiába kertvárosi környezetben voltak az odúk, a különbség így is érezhető volt az erdőhöz képest. SZIRÁKI GYÖRGY: A kertváros kedvező is lehet a táplálék szempontjából. BUKOR BOGLÁRKA: Ugyanakkor az ilyen élőhelyen permeteznek. SZÖVÉNYI GERGELY arról érdeklődött, hogy van-e az előadónak saját adata arra, hogy a környező erdőterületről beköltöznek egyedek a városba. Előadó válaszából kiderült, hogy a két terület nem szomszédos közvetlenül egymással, és a betelepülést esetleg jeladóval lehetne vizsgálni.

3. Balogh diána, Péntek Attila László és VÁGi BAlázs: A zöld gyík élöhelyhasználata a Gödöllöi-dombság területén.

Habár a zöld gyík hazánkban általánosan elterjedt, a populációk egyedszáma alacsony. A példányok nagy mozgáskörzetet igényelnek, ezért élőhelyük feldarabolódása jelentős veszélyeztető tényező számukra. Amellett, hogy nálunk védett, és szerepel az Európai Unió Élőhely Irányelvének IV. függelékében is, más igen értékes fajoknak (kaszpi haragossikló, kígyászölyv) fontos táplálékállata. Szerzők azt vizsgálták, hogy eltér-e a fiatal és a kifejlett, valamint az adult hím és nőstény egyedek élőhelyválasztása és/vagy búvóhelyhasználata, és a faj megőrzésében használható eredményeket vártak. Domonyvölgy-Bárányjárás fokozottan védett területén végezték a kutatást, melyen az akác, gyalogakác és egyéb idegenhonos növények irtása történik. Előadó egy zárt erdőrészt nem tudott átvizsgálni, ezen kívül az egész területet kétszer járta be, és bolyongásos kereséssel igyekezett gyíkokat találni. Az egyed alapadatait, megfigyelésének pontos idejét, helyét, valamint tartózkodási helyének növényzeti jellemzőit jegyezte fel. Térinformatikai és statisztikai programokat használt adatainak kiértékeléséhez. Eredményül megkapta a terület élőhelytérképét, 117 gyík-egyedet talált, ezek több mint negyede (33 példány) fiatal. Az adott élőhely területi arányából származtatott várt értékeknél többet tartózkodtak az egyedek nyílt cserjésben és szegélyben, míg a vártnál jóval kevesebbet a gyepben. A fiatal egyedek átlagosan alacsonyabb növényzetben voltak, mint a kifejlettek, és cserjékhez közelebb lehetett rájuk találni, mint a felnőttekre. A hímek naposabb helyeken tanyáztak, mint a nőstények; a hímek színe a napon jobban érvényesül, és jobban is fejlődik ki. A felnőtt egyedek sokkal inkább menekültek cserjék közé, mint a fiatalok; utóbbiak viszont jóval többször menekültek gyepbe, mint a kifejlettek. A felnőttek közül a hímek jóval többször bújtak farakásba, mint a nőstények. Szerzők az eredményekből arra következtettek, hogy a zöld gyík a nagyobb fümagasságot, sürü vegetációt, cserjék jelenlétét és az erdő közelségét preferálja, de a zárt erdőket (csakúgy, mint a nyílt talajfelszíneket) kerüli. A zöld gyíknak a mozaikos élőhely a legjobb, a 
terület kezelése során erre kell törekedni legeltetéssel, kaszálással, cserjeirtással, farakások meghagyásával. További adatok nyerése fontos lenne egyedek jeladóval történő ellátása és nyomonkövetése által. Az előadás után SzIRÁKI GYÖRGY tette fel kérdését: Mi alapján állapították meg a várható értékeket? BALOGH DiÁNA: Az előhelytípus kiterjedése alapján. SzIRÁKI GYÖRGY: Ha a zöld gyíkot egy fokozottan védett faj eszi, akkor nem kellene a zsákmányfajnak többlet-búvóhelyet készíteni. Előadó jogosnak tartotta ezt az észrevételt. SZIRÁKI GYÖRGY megjegyezte, hogy az árnyékoltság arányában igen kicsi a különbség az ivarok között. Elöadó elmondta, hogy a különbség épphogy szignifikáns, viszont PÉNTEK ATTILA LÁSZLÓ javította: A különbség nem szignifikáns, csak ahhoz közeli. PÉCSI LÁSZLÓ arra volt kíváncsi, hogy csak két életkor-kategóriát állítottak-e fel. Előadó szerint igen, ugyanis ha már megállapítható, hogy mely ivarhoz tartozik az egyed, akkor adultnak vették. PÉCSI LÁsZLÓ: Él a területen haragos sikló? BALOGH DIÁNA: E faj nem, de rézsikló él, és az is fogyaszt zöld gyíkot.

4. TÖRÖK JÚLIA KATALIN és BÉRES TIBOR: Egy csepp tenger - mikroszkóppal az adriai plankton nyomában.

Előadó számára a téma azért különösen kedves, mert adriai utazásai alkalmával az 1969-es, Dudich-Loksa-féle Állatrendszertan tankönyv megelevenedik elötte. Magyar kutatók már a XIX. század végétől (pl. ENTZ GÉZA) járnak az Adriai-tengerre. A bemutatott fényképeket sztereomikroszkóp alatt készítette, majd ezek minőségét utómunkával javította. A továbbiakban e képekből láthattunk válogatást: A Chaetoceros spp. alga megnyúlt telepeket alkot a zsákmányul esés elleni védekezésként. Változatos alakú házakkal rendelkezö Dinoflagellata fajokat is láthattunk. E csoport jelentősége abban áll, hogy nyár közepi elszaporodásuk idején fogyaszthatatlanná tehetik az ember számára a kagylókat, mert toxinokat termelnek. Azonban a Dinoflagellata fajoknak is vannak fogyasztói, a "harangos állatkák". A sugárállatkák érdekessége, hogy belső citoplazmájukban algák vannak, ezért a fotikus zónában tartózkodnak, vertikálisan mozognak. Az előadó a Phaeodaria példányokat csak nehezen tudta azonosítani, ugyanis ezt a csoportot kizárólag a Dudich-Loksa-féle tankönyvben találta meg (Radiolaria-szerü lények, de ma más csoportba sorolják). A Foraminifera fajokra üledékminta vételével lehet szert tenni, mert csak ritkán találhatók a plankton között. Hoplitomella lárvát is láthattunk, ez olyan fúrószivacs lárvája, amely korallba fúr. Hovatartozása még egy helybéli kutató számára is újdonság volt. Az amphiblastula lárva néhány mészszivacs fejlődési alakja, emellett bemutatásra került egy nyolcosztatú korall planula lárvája is. Az echinospira lárva viszont már a puhatestủek egy speciális veligeralárva-változata, melyből porceláncsiga fejlődik, és fehérjéből felépülö, tüskékkel díszített háza van. A Pteropoda (tengeri pillangók) fajoknál nemcsak lárva, hanem a kifejlett állat is planktonikus életmódot folytat. A soksertéjü gyürüsférgeket az elöadásban a cincérféreg képviselte, melynél a kifejlett állat is a planktonban található. A soksertéjủeknek mitraria lárvája is lehet, melynek érdekessége, hogy sokáig az újszájúak lárvaalakjához közelebb állónak vélték, ám később kiderült, hogy egy speciális trochophora lárváról van szó. Sokféle rákot is láthattunk: a Cumacea csoportnak csak sósvízi fajaik vannak, aljzathoz közeli életmódot folytatnak, ám éjszaka fényre jönnek; a Mysida rend bizonyos fajai viaszrózsa karjai közt tartózkodnak, és csak ügyességükkel kerülhetik el a zsákmánnyá válást, mert nincs védelmük a rózsa ellen; látványosak voltak a tüskés zoëa lárvák is. Az újszájúak közül láthattunk nyílférget (Chaetognatha); farkos zsákállatot, melynek nincs lárvaállapota; aszcídiát (Ascidiacea), mely csak rövid ideig tagja a planktonnak, utána 
helyt ülö életmódot folytat; és mikroszalpákat, melyek között 1-2 mm-es fajok is vannak, testükbe más planktont ágyaznak. Az előadás után kérdések következtek: JÁNOSSY LÁsZLÓ vitorlázás közben tapasztalta, hogy a vízben világító plankton látható éjjel, a hajó WCjében is megjelenik, ennek hovatartozását szerette volna megtudni. Elöadó szerint ezek egyes Dinoflagellata fajok, melyek vízáramlási ingerre reagálnak világítással (pl. Noctiluca scintillans). Lehetséges, hogy a predáció ellen fejlődött ki ez a viselkedés. JÁNOSSY LÁszLÓ: Régen sok állatot lehetett látni a sziklákon, most alig vannak. Ez trendszerü változás? TÖRÖK JÚLIA KATALIN: Éves ingadozások vannak, pl. egyes években a hideg február miatt a partközeli flóra és fauna nagy része elpusztult vagy mélyebb vizekbe húzódott. Erős áramlású helyeken is kevesebb lény látható, mint nyugodtabb vizekben.

\section{9. előadóülés, 2017. április 5-én.}

Kihelyezett előadóülés volt, melynek az ELTE Savaria Egyetemi Központja adott otthont Szombathelyen. Az ülés levezető elnöke ezúttal SzINETÁr CSABA volt.

\section{NAGY PÉTER: Az Állattani Szakosztály rövid bemutatása}

A hallgatóság köszöntése és a szombathelyi intézménynek mondott köszönetnyilvánítás után Előadó megemlítette, hogy ez a harmadik, külső helyszínen megtartott előadóülés (Szeged és Tihany után). Azért fontos külső helyszíneken is rendezni üléseket, mert Társaságunk az egész országra kiterjed, továbbá a tagság, ill. az ülések látogatottsága ilyen módon növelhetö. Az Állattani Szakosztály történetéböl kiemelte, hogy 1891-ben alakították meg azért, mert ebben az időben az új ismeretek gyarapodása nagy mértéket öltött, és igény mutatkozott arra, hogy a többféle tudományágat ne egy nagy univerzális társaság fogja öszsze, hanem kisebb, specializált körökben lehessen az érdeklődők elé tárni az új eredményeket, elméleteket. Azóta a megpróbáltatások, világégések és az anyaszervezet megváltozásának ellenére rendszeresen, a hónapok első szerdáján tartotta üléseit. Jelenleg a Magyar Biológiai Társaság egyik legaktívabb szakosztálya, immár túl az ezredik előadóülésen. A fiatalok bevonása (utánpótlás) mindig fontos volt az idősek ("húzónevek") érdemeinek elismerése mellett. Az Állattani Szakosztály történetéröl részletesen az Állattani Közlemények 97. kötetében megjelent, KORSÓs ZOLTÁN által írt cikkben lehet olvasni. Az üléseken előadás tartása egyetemi hallgatóknak jó lehetőség arra, hogy készülő TDK-dolgozatukat, diplomamunkájukat a szakma elé tárják és a visszajelzések alapján tökéletesítsék, sőt, megjelent (vagy elfogadott) cikkük a doktori felvételiken is többletpontokat jelent. Végül szintén egy nagy múltú hagyományt folytatva - körbeadta a hallgatóság között a Szakosztály vendégkönyvét.

\section{GYURÁCZ JÓZSEF: Az ELTE Savaria Biológiai Tanszék rövid bemutatása}

Előadó megtiszteltetésnek nevezte, hogy e nagymúltú Szakosztály az ő intézményét választotta a kihelyezett ülés helyszínéül. 1984-ben indult Szombathelyen a biológia tanárok képzése. Az első nagy változás a bolognai rendszer bevezetése volt, a képzési struktúrát itt is teljesen át kellett alakítani, az infrastruktúrát jelentősen bővíteni. 2008-ban csatlakoztak a Nyugat-magyarországi Egyetemhez, ahol már nagy hagyománya van a természettudományok oktatásának, ennek ellenére a kémia-, fizika- és matematikatanárok képzését még nem tudták elindítani, hallgatóhiány miatt. 2016-ban az ELTE szervezetébe került, és az 
előbb említett tanárszakok már létrejöhettek. Reméli, hogy hagyományaikat megőrizve, specifikus kutatási témákat találva megtalálják helyüket ebben a szervezeti felépítésben.

3. GYURÁCZ JózSEF, BÁNHIDI PÉTER, GÓCZÁN JÓZSEF, ILlÉs PÉTER, KALMÁR SÁNDOR, KOSZORÚS PÉTER, LUKÁCS ZOLTÁN, NÉMETH CSABA és VARGA LÁsZLÓ: Madárpopulációk dinamikája 2001 és 2016 között a Tömördi Madárvárta madárgyürüzési adatai alapján

Kutatásuknak, melyet kezdetektől az MME tagjaival közösen végeznek, fő kérdései: milyen az egyes fajok populációdinamikája és vonulási stratégiája (időzítés ivaronként és korcsoportonként, preferált területek, befolyásoló időjárási és környezeti tényezők); merre húzódnak a vonulási útvonalak; milyen a fajok fészkelö- és pihenőhelyekhez való hüsége; a párok kapcsolata mennyi időre szól; és milyen élettartamúak az egyedek. Szerzők a populáció fogalmát a szokásostól eltérően értelmezték: ez náluk az adott időszakban egy fajból befogott egyedek összességét jelenti. Feltételezik, hogy tulajdonságaik (kor- és ivararány, átlagos testtömeg) hasonlók az országos állományéhoz. A vizsgálati terület a tömördi "Nagy-tó" - egy mocsaras terület, és a vele szomszédos erdőfolt. Beavatkozások történnek a cserjék és a vizes foltok területének állandóan tartására. Szerzők nemzetközi programokhoz csatlakoztak, standard felületủ és helyzetủ hálókat használnak, a befogások idejét öszszehangolták. A gyürüzés segítségével vizsgálhatók a madárpopulációk, ugyanis a populáció történéseinek megfigyelése csak az egyedek nyomon követésével lehetséges. Bázisévnek a vizsgálatok kezdetét, 2001-et jelölték ki, ehhez képest évente egyedszámváltozási mutatókat számoltak. Összesen 135 fajt fogtak, hosszútávon 50 fajt vizsgáltak. A legtöbb egyed barátposzátából és vörösbegyböl érkezett. Tíz faj egyedszáma lényegesen csökkent a vizsgálati idő alatt, míg öt fajé lényegesen nőtt - ez utóbbiak állományai Magyarországon és egész Európában is hasonló mértékben nőttek (a többi fajnál nem találtak statisztikailag kimutatható változást). A csökkenő állományú fajok zöme agrárkörnyezetben él, ám egy faj tág türésü. A növekedő trendet mutató fajok mindegyike erdőkhöz kötődik. Az énekes rigó Európában egyre északabbra terjed. A vonulási stratégia szerint a csökkenő állományú fajok nagy része hosszú távú vonuló, míg a növekvő állományú fajok mindegyike rövidtávú vonuló. A továbbiakban néhány fajt emelt ki az előadó. Az erdei pityer példája azt igazolja, hogy a különböző területi léptékben megfigyelt egyedszámváltozási trendek nem feltétlenül vágnak egybe: e faj populációja helyileg csökken, országosan stabil, míg Európában csökken. Molnárfecskéből az utóbbi öt évben egyet sem fogtak, és füsti fecskéből is nagyon keveset. A mezei veréb populációjának csökkenése a vizsgált területen nagyobb mértékủ volt, mint országosan, de Nyugat-Európában a jelen vizsgálathoz hasonló mértékben csökkent. A kékcinege gyakran mutat nagy éves fluktuációkat. Összefoglalva elmondható, hogy az agrárkörnyezet egyes fajokra kedvezően hat, függetlenül azok vonulási stratégiájától; ennek megfelelően az Európai Unió agrárstratégiája revízióra szorul. A klímaváltozás helyi hatásai miatt az obligát hosszú távú vonulók veszélyeztetettek, ezek megóvására nemzetközi együttmüködés szükséges. SzÖVÉNYI GERGELY arról érdeklödött, hogy milyen konkrét intézkedéseket lehetne javasolni az ismertetett problémák kezelésére, orvoslására. Előadó válaszában komoly problémaként kiemelte az agrárterületek élőhely-diverzitásának csökkenését a bokrok, cserjék és erdősávok irtása (költési időszakban is), valamint a mindenféle búvóhelyek nélküli, nagyüzemi táblák kialakítása miatt - ezek korrekciójára szükség lenne. Fecskék esetében gond a nagyüzemi állattartás visszaszorulása és a sárgyüjtő helyek csökkenése. E problémák pusztán civil lakossági aktivitással nehezen kezelhetők, állami beavatkozással kellene segíteni e fajok helyzetén. A 
megfigyeléseken és gyürüzési adatokon alapuló eredmények összevethetők a régebb óta ismert nyugat-európai adatokkal. A fenti negatív hatások az EU csatlakozás után erősödtek fel. A jelenlegi támogatási rendszeren is változtatni kellene.

4. Szentirmai IstVÁn, Faragó ÁdÁm, Németh TamÁs Márton és Farkas dóRA: A haris (Crex crex) védelmét megalapozó ökológiai kutatások az Örségi Nemzeti Parkban.

Előadó örül minden kapcsolatnak a tudomány képviselöivel, mert ezekből kölcsönös segítséget kapnak a felek. A fajról kevés ismeretünk van, az is föként Nyugat-Európából származik, ahol viszont az élőhelyi viszonyok jelentősen eltérnek a hazaiaktól, ezért nehéz e kutatásokból általános következtetéseket levonni. Bemutatta a haris hangját. A faj helyzete globálisan ellentmondásos. Időről-időre észlelik akár milliós populációit is (Oroszország, Ukrajna), ám ezek erősen fluktuálhatnak. Európában máshol ritka faj, így a hazai helyzete is nagyon fontos. Nálunk fokozottan védett, föleg az Aggteleki-karszton és környékén, a Bodrogzugban és Szatmár-Beregben fordul elő, de alacsony egyedszámban sok más területen is él. Az elmúlt tíz évben kb. 55\%-al csökkent hazai állománya elsősorban az agrárélőhelyek megváltozott használatának következtében, de nagy fluktuációkat mutat. Konkrét fő ok a kaszálások rossz időzítése, amely így egybeesik a költési időszakkal. A Örségi Nemzeti Park területén is drasztikusan fogyott az állomány: a korábbi kb. 30 revírből 2011-re egy sem maradt. Azóta megint megjelent a faj, de mindenképp védelemre szorul. A haris nem feltétlenül fogható és gyürüzhető, távcsővel is nehéz észlelni, ezért vizsgálata speciális felkészültséget igényel. Egyik kutatási kérdésük, hogy a növényzet és a táplálékellátottság miként befolyásolja az élőhelyválasztást. Irodalmi adatok alapján májusban min. $20 \mathrm{~cm}$ magas vegetációt igényel. Elöször hang alapján vizsgálták a madarakat. Három kategóriába sorolták a korábban harisnak otthont adó területeket: „territórium”, „lakatlan”, „,korábban lakott". A territóriumokban valamivel magasabb a növényzet, nagyobb a borítás, azonban - bár szignifikáns - de nagyon kicsi a különbség a többi területhez képest. Vizsgálták a táji környezetet is, de nem igazán találtak különbséget a háromféle kategória között. Ezt követően hat-hat hímre és tojóra szereltek rádióadót, és az így nyert telemetriás adatokból olyan élöhely-használati paramétereket sikerült megállapítaniuk, mint a territóriumok lehatárolása, valamint a legtöbbet és legkevesebbet használt gyepfoltok elkülönítése. E kétféle foltot összehasonlították a növényzet magassága, borítása, fajösszetétele és talajcsapdázási-fühálózási adatok alapján. Eredményeik szerint nagyon közel kerülhettek a madarak életéhez, kiderült, hogy mely 2-3 hektáros foltokat használják. A hímek a kaszálást követően elvándoroltak, ill. júliusban a párok másodköltéseket végeztek. Ebböl következöen adaptív kezelési módokat állapítottak meg: a kaszálást el kell halasztani augusztus 15-ig még a tágabb környéken is, mivel ez erősen zavaró; minél nagyobb, összefüggő zavartalan élőhelyeket kell meghagyni a harisok számára. Ugyanakkor nem találtak összefüggést a haris által a területen töltött idő és a növényzet tulajdonságai ill. a táplálékellátottság között, ennek oka talán a kis élőhelyi lépték vagy a telemetriás mérések pontatlansága. Szerzők a továbbiakban élőhelykezelési és -fejlesztési kísérleteket szeretnének végezni, valamint mühold-alapú egyedi nyomkövetést terveznek a diszperzió feltárására, mindezek segítségével az Örségi Nemzeti Park területén található állományt meg szeretnék duplázni. Igyekeznek olyan, a Nemzeti Park Igazgatóság kezelésében lévő területekre összpontosítani az állományt, amelyeket a haris számára kedvezően alakítanak ki: változatossá teszik a gyepeket kaszálatlan sávok, cserjecsoportok, stb. meghagyása által. 
5. Szinetár Csaba, Kovács Péter, Eichardt JÁnos, TakÁcs GÁbor, TÖrÖK TAMÁs, KAUsits ANITA, SzABÓ MÁRTON és VÖRÖSHÁZI TIBOR: A kisalföldi meszes homokpuszta pókfaunájának kutatása 2004-2016 között.

Előadó a kutatás előzményeinek bemutatásával indított: a Nemzeti Biodiverzitásmonitorozó Rendszer keretében egy 14 éves vizsgálatsorozatot tudtak végezni a száraz gyepek talajfelszíni ízeltlábúinak monitorozására a Nyírség, a Kiskunság és a Kisalföld területén. Ez volt az első ilyen jellegü vizsgálat hazánkban. Botanikusok már jeleztek a Kisalföld több területéről értékes fajokat. Mai napig a győrszentiváni erdő, a gönyüi lőtér, a Bőnyi-erdő és a nagyszentjánosi gyep területén maradtak meg értékes homokpusztafoltok. Módosított Barber-féle talajcsapdákat használtak, minden mintavételi helyre 10-10 csapdát helyeztek ki. Április 15. és május 15. között 2x2 héten át zajlott mintavétel (néhol 2004 óta folyamatosan), mely során 13199 pókegyedet gyüjtöttek és határoztak meg, melyek 199 fajhoz tartoznak (a hazai fauna több, mint negyede), közülük három hazánk faunára új, egy tudományra új, és egynek eddig nem volt ismert a nősténye. Számos más ritkaság és négy védett faj is előkerült. Vizsgálták a fajok nedvesség- és fénypreferenciáját, e jellemzők alapján az alábbi kategóriákat állítottak fel: tágtürésü fajok; füves élőhelyeken élő, de a nedvesség iránt viszonylag közömbös fajok; nyílt és száraz élöhelyeket igénylő fajok; közöttük a specifikusan homokhoz kötődő típussal; végül a környező élőhelyekröl bejutott fajok. Legnagyobb arányban a Kisalföldön és a Nagyalföldön is a nyílt és száraz élöhelyekre (alapkőzettől függetlenül) jellemző fajok voltak jelen, míg a legkisebb (4 ill. 8 \%) az igazi pszammofil fajok aránya. Vannak közös fajok a Nagy- és Kisalföld közt, de egyes nagyalföldi fajok már nem jutnak nyugatabbra (az irodalomban hasonló botanikai eredmények olvashatók). A tudományra új faj a Parasyrisca arrabonica SzINETÁR \& EICHARDT, 2009. Különlegesség volt a Zodariaon zorba elöfordulása: korábban egy hím alapján írták le a Peloponnészoszi-félszigetről, ahonnan feltételezésük szerint az itteni katonai területet is használó NATO-alakulatok hozhatták be. 2013 óta egyre többet fognak. Mirmekofil, a Lasius psammophilus hangyával élhet együtt. A nősténye leírása került. A Mermesus trilobatus valószínűleg az első igazi özönfaj a pókok között, melyet hazánkban először a vizsgált területen sikerült detektálni, 2012-ben. Az Alopecosa psammophila faj előfordulását várták, mert hazánk más homokterületein elterjedt. Degradált gyepfelszínek élőhelyrekonstrukciós munkálatainak sikerességét is jelezhetik a pókfauna változásai, az agrobiont (bolygatottságot jelző) fajok visszaszorulása, ill. a természetes gyepekre jellemző fajok megjelenése révén (először a száraz gyepeket jelző tágtürésűek bukkannak fel).

6. SzÜts TAmás, Nikolaj ScharfF, Charles Griswold, DARrell Ubick, Jeremy MILLER és WAYNE MADDISON: A fába szorult lényeg: pókrendszertani kutatások.

Előadó bemutatta a társszerzőket, akik között taxonómusokat éppúgy találunk, mint filogenetikusokat. Az előadás abban tér el a korábban elhangzottaktól, hogy több kutatási témából villant fel érdekességeket, ám mivel ezek még folyamatban vannak, eredményeket összefoglalóan még nem tud a hallgatóság elé tárni. Előadó érdeklődése kiterjed a diverzitás, a taxonómia, a morfológia és a leszármazás területeire is. Hangsúlyozta, hogy egy törzsfa csak az adataink grafikai megjelenítése, ha nincs mögötte evolúciós kérdés, akkor nem lehet kiolvasni belöle semmi lényeges információt. A továbbiakban a kutatási területeit mutatta be. (1) Foglalkozik Nemesia fajokkal, és arra jutott, hogy nálunk nem a (hazánkban védett) $N$. pannonica él - annak a mai Szerbiában van a típuslelöhelye - hanem egy, vagy inkább több másik faj (a Magyar Természettudományi Múzeum gyüjteménye alapján). Az 
eredményeket molekuláris módszerekkel kellene alátámasztani, ezek alkalmazása még hátravan. (2) A "Hamupipőke pókoknál" a lábon található ivarszervet kell vizsgálni a családhoz tartozás megállapításához. Elkészítették a család molekuláris alapú törzsfáját, melyet összevetettek a fajok elterjedésével, erről szóló cikkük hamarosan megjelenik. Új fajt, sőt genuszt is találtak, de ezek elhelyezése a családon belül még várat magára, mivel még nem tudtak kinyerni belölük molekuláris információt, viszont a család morfológiai törzsfája még nem áll rendelkezésre. (3) "A Csipkerózsika pókok családja" Afrikában, Dél-Amerikában, Ausztráliában és Új-Zélandon terjedt el. Egy közelmúltban leírt kenyai fajuk a molekuláris adatok szerint egy ausztráliai endemikus genuszba illeszkedik. Szerzők e családban is öszszevetették a molekuláris törzsfát a biogeográfiai információkkal, és a következő kép rajzolódott ki: a csoport Ausztráliában alakult ki, majd másodlagos fajképződési gócok jöttek létre Afrikában. A leginkább leszármazott, az előzőektől eltérő kládhoz tartozó fajok ÚjZélandon élnek. (4) Keresztespókok: néhány fajnak több nyílása van a fonószemölcsön, mint ami a családra jellemző, ezek pásztázó elektronmikroszkópos vizsgálata speciális technikák alkalmazását igényli. A többnyílású fajok a többi csoporttal keverten helyezkedtek el az eddig legjobbnak tartott törzsfán, de aztán egy tanulmány nyomán a több nyílás jellegállapota szünapomorfia lett a családban. (5) Fekete özvegyek: egy revízió során a molekuláris fán néhány morfológiai faj több helyen is felbukkant. E jelenség oka az, hogy az ivarszervnek csak egy kis része vizsgálható természetes pozícióban, és a fajok lehatárolásához eddig csak ezt a részt vették igénybe. Az ivarszerveket ki kell boncolni nagy (fél napos) munkával, így egészen más bélyegek válnak láthatóvá - ezen új eredmények alapján a fajok közti morfológiai alapú határokat módosítani kell. (6) Bikapókok: nálunk három, feketepiros fajuk honos. Léteznek fekete-fehér fajok is, ám kérdéses, hogy egy genuszba tartoznak-e a fekete-piros taxonokkal. Egy közelrokon, mediterrán genusznak sokáig egyetlen faját ismerték, és csak a legutóbbi időben derült ki, hogy legalább 5-6, zömmel még leíratlan faj tartozik ide. (7) Ugrópókok: Szerzők különböző genuszok ivarszerveinek homológiáit vizsgálták, ami alapján megalkották a család új rendszerét. Legalább 11 alkalommal alakultak ki hangyautánzó formák az evolúció során, egymástól függetlenül. Legnagyobb hazai fajuk (Myrmarachne formicaria) egy ausztrálázsiai klád tagja. Egy újguineai faj külsőleg pókszerü, de ivarszervei igen hasonlítanak a M. formicaria fajéhoz, így az újabb eredmények a hangyaszerüvé válás folyamatának megértését is segíthetik (legalábbis az egyik leszármazási vonalon).

\section{0. előadóülés, 2017. május 3-án}

Az elöadóülést NAGY PÉTER elnök úr vezette le. Bevezetőjében kiemelte, hogy örvendetes módon ennek az ülésnek összes előadója a fiatal egyetemista generációból kerül ki, és mindegyiküknek ez az első előadása az Állattani Szakosztály köreiben.

1. Szabó Gyula, Boross Nóra, Garamszegi lászló Zsolt, Hegyi Gergely, Jablonszky Mónika, KRenhardt Katalin, Laczi Miklós, Markó Gábor, SZÁsz ESZTER és TÖRÖK JÁNOS: Fiziológiai és viselkedési változók kapcsolata örvös légykapónál.

Énekesmadár-populációk viselkedésének terepi vizsgálata nemrég kezdődött, mert nehéz mérni a változókat. Szerzők örvös légykapó (Ficedula albicollis) egyedekböl vettek 
vért az udvarlási és költési időszakban; elöbbi időszakban 19 hímből, utóbbi periódusban hím és nőstény egyedekből (összesen több mint 100 egyedből) egyaránt. A következő fiziológiai tulajdonságokat vizsgálták az egyedeken: (1) egészségi állapot, melyet a heterofil granulociták és limfociták arányával (H/L) jellemeztek, e sejteket vérkeneten számolták; (2) a hematokrit érték a kondíciót mutatja, melyet a vörösvértestek és a vér teljes térfogatának arányával fejeztek ki; (3) oxidatív stressz, melyet a reaktív oxigénmetabolitok jelenlétével jellemeztek. A viselkedési változók közül a kíváncsiságot azzal az időtartammal fejezték ki, amíg az egyed egy számára ismeretlen tárgyat megközelít; az agresszió pedig azzal az idővel került jellemzésre, amely egy idegen hímre való támadásig eltelt. A vizsgálat során kiderült, hogy a fiatal hímeknél a hematokrit érték alacsonyabb, míg az oxidatív stressz magasabb az udvarlási időszakban, mint a költési időben; a nöstények nem mutattak ilyen különbséget. A hematokrit érték és a fehérvérsejt-szám egyenes arányt mutatott egymással a tojóknál, ám a hímeknél nem. Hasonlóképpen a reaktív metabolitok mennyisége és a H/L érték is csak a tojóknál álltak egyenes arányban. A kíváncsibb egyedekben nagyobb mértékủ oxidatív stressz volt tapasztalható, mint a kevésbé kíváncsiaknál, ám más viselkedési változó nem korrelált egyetlen élettani változóval sem. A vonulásból visszatérő fiatal hímek oxidatív stresszének változását Szerzők azzal magyarázták, hogy a szezonon belül a madarakat maláriával fertőző parazita prevalenciája csökken, továbbá más fajon végzett vizsgálatok kimutatták, hogy vonuláskor az idősebb egyedeknek nagyobb az enzimatikus aktivitása, mely csökkenti a stressz mértékét. A hematokrit érték és $\mathrm{H} / \mathrm{L}$ arány közötti öszszefüggés magyarázata lehet egyrészt, hogy a fertőzés (kevésbé jó kondíció) miatt az L értéke nő (H nem változik), és a hematokrit érték csökken. Másrészt a jobb kondíciójú hímek értékesebb territóriumot tudnak foglalni, ám ennek megtartása több energiát igényel; továbbá a nagyobb energiaigényü egyedeknél immunszuppresszió alakul ki, amely L értékét csökkenti, és ez a $\mathrm{H} / \mathrm{L}$ arány növekedésével jár. A kíváncsiság és az oxidatív károsodás között egy korábbi, zöldikéket laboratóriumi körülmények között vizsgáló munka eredményeivel megegyezö összefüggést mutattak ki. Szerzők a továbbiakban szeretnék a 2016-ban vett vérmintákon is elvégezni a vizsgálatokat, és szeretnék megismerni a vérplazma teljes oxidatívgyök-semlegesítő kapacitását. Az előadás végén NAGY PÉTER érdeklődött a felől, hogy az e madarakat fertőző maláriatörzsek veszélyesek lehetnek-e emberre is. A válaszból megtudtuk, hogy a kórokozó- és madárfajok közötti koevolúció jelenleg még újszerủ kutatási téma. Bár a madáregyedek túlnyomó többsége fertőzött, ám ezek a kórokozók gyakran madárfaj-specifikusak, emberre nem képesek átterjedni.

2. KonRÁd KRISZTina és HaRnos AndRea: Az erdei szürkebegy (Prunella modularis) vonulása.

Az erdei szürkebegy Eurázsia mérsékelt övi lombhullató, tülevelü és elegyes erdeiben élő faj, mely a vegetációs időszakban főleg rovarokkal, azon kívül magvakkal táplálkozik. Hazánkban a törzsalak honos, mely elterjedési területének déli részén részleges, máshol obligát vonuló. Vonulása nagyjából észak-déli irányú. Szerzők vizsgálni szerették volna az egyedek testméretét és a vonulás időzítését, valamint szerették volna összehasonlítani e tulajdonságokat az elmúlt 32 év adataival. Időjárási adatokat is rögzítettek. Két korcsoportot különböztettek meg: az 1 évesnél idősebb madarakat öregnek, a fiatalabbakat fiatalnak tekintették. Kiderült, hogy a vonuló madarak március közepétől április végéig, ill. szeptember elejétől november közepéig tartózkodnak nálunk, egy-egy jól körülhatárolható egyedszám-csúccsal. Ezek az időzítések jól illeszkednek a vonulási sáv más országaiban 
megfigyelt periódusokhoz. Az öreg madarak szárnyhossza és testtömege igen hasonló volt tavasszal és ősszel. A tavaszi vonulási időszak elején hosszabb szárnyú és nagyobb tömegü madarak érkeznek, mint a végén. Összel éppen fordított jelenség tapasztalható - a nagyobb madarak valószínüleg jobban bírják a hideget, mint kisebb fajtársaik. A korábbi évekből kiderült, hogy melegebb március esetén korábban zajlott a tavaszi vonulás, ám az őszi időszakban nem találtak összefüggést az időzítés és a hömérséklet között. A testtömeg ősszel kisebb, mint tavasszal, továbbá a melegebb augusztusokban kisebb volt a testtömeg, mint más évek hűvösebb augusztusaiban; valószínűleg a táplálékbázis csökkenése miatt. Összefoglalva elmondható, hogy a vonulási stratégia változatlan maradt, és valószínüleg ugyanaz a populáció jelenik meg nálunk a tavaszi és az őszi vonulás során is. Az előadás után hoszszú eszmecsere bontakozott ki. NAGY PÉTER arra volt kíváncsi, hogy bár kimutatták a környezeti feltételek romlását, de vajon klimatikus változást is sikerült-e detektálni. Előadó elmondta, hogy az augusztusi hőmérsékletek emelkedtek, de a szeptemberi és októberi adatok nem mutattak ilyen trendet. SZÖVÉNYI GERGELY kérdése az volt, hogy várnánk a vonulás eltolódását a hőmérséklet változása miatt, van-e erre adat az irodalomban. KONRÁD KRISZTINA: Sokféle eredmény született, egyes esetekben igen, míg máskor nem látszik eltolódás. SZÖVÉNYI GERGELY szerette volna tudni még, hogy 30 év elég-e az ilyen jelenségek kimutatására. Előadó válaszából kiderült, hogy igen, elég. SzÖVÉNYI GERGELY megkérdezte még, hogy biztosan lineáris változást várunk-e. A válasz szerint igen. SzÖVÉNYI GERGELY utolsó kérdése az volt, hogy az április hőmérsékletek nem változtak-e, és azt a választ kapta, hogy bár változtak, de a márciusiak nagyon szórtak, ezért arra hónapra nem rajzolódott ki trend. PÉCSI LÁSZLÓ megosztotta a hallgatósággal megfigyelését, miszerint a Szentendrei-szigeten és környékén helyenként a faj jelenleg áttelel. A válaszból megtudhattuk, hogy az 1990-es években már feljegyeztek telelést, de a későbbi években már nem történt ilyen. TÖRÖK JÁNOS megjegyezte, hogy az őszi testtömegcsökkenés trendje valahol meg fog állni, "nem fogynak le 1 grammosra a madarak". Beszámolt arról, hogy ilyen összefüggést az ő kutatócsoportja is talált, továbbá megkérdezte, miért nem konkrét hőmérsékletváltozás függvényében nézték a testtömeg csökkenését. Előadó válaszában kiemelte, hogy ennek függvényében nézték, és megismételte azon eredményüket, hogy meleg augusztusok elején kisebb a madarak tömege, mint hüvösebb augusztusokban.

\section{Drexler tamás, UjSZegi János és HetTyey AtTILA: Két hazai kétéltüfaj} kitridiomikózissal szembeni fogékonysága és érzékenysége.

A kétéltűek kitridiomikózis fertőzését a Batrachochytrium dendrobatidis gomba (továbbiakban Bd) okozza. Világszerte drasztikus állománycsökkenéssel, sőt helyenként fajok kipusztulásával járó fertőzés, mely ebihalakon kevésbé jelentkezik, ám az átalakulás után a teljes testfelületre kiterjed. Hiperkeratózissal, a bőr hámlásával jár, ami a bőrön át zajló anyagcserét - esetenként a légzést is - végzetesen megzavarja. Szubletális hatásként testtömegcsökkenés lép fel, ugyanis a fertőzés magas energiaköltséggel jár. A gomba minden kontinensen jelen van, széles gazdaspektrummal bír. Tömeges pusztulást főleg az Újvilágban, Ausztráliában és Spanyolországban okozott, Európa más részein még kevésbé jelent gondot. A területi eltérés oka lehet, hogy az itteni törzsek kevésbé virulensek, esetleg az itt honos kétéltúek ellenállóbbak. Előadó két alapfogalmat tisztázott: magas rezisztenciáról akkor beszélünk, ha a $\mathrm{Bd}$ megtelepedési valószínüsége igen alacsony, míg a magas tolerancia az az állapot, amikor a fertőzés nem okoz betegséget. A Pilisből származó erdei béka és barna varangy egyedeken vizsgálták, mennyire fogékonyak és érzékenyek a fertőzésre. 
Összesen 216 egyedet fertőztek laboratóriumban egy magas virulenciájú törzzsel heti két alkalommal. Az egyedek egy részét ebihalkorban, a többit metamorfózis idején fertőzték alacsony, vagy magas spórakoncentrációval (kontrollcsoport meghagyása mellett). Az erdei béka ebihal- és átalakulási korban egyaránt elhanyagolható mértékben szenvedett fertőzést, és mortalitás nem volt. Szubletális hatást sem mutattak ki a szerzők. A barna varangynál a kezelésnek nem volt szignifikáns hatása a túlélésre, bár a prevalencia magasabb volt, mint az erdei békánál. Szubletális hatást ennél a fajnál sem regisztráltak, bár a metamorf fázisban magas Bd dózissal kezelt egyedek közül a kisebb tömegüek szignifikánsan jobban fertőződtek. Összefoglalva elmondható, hogy az erdei béka rezisztens a Bd-re, míg a barna varangy toleráns vele szemben. A továbbiakban a szerzők a rezisztencia és tolerancia kémiai hátterét szeretnék vizsgálni. NAGY PÉTER szerette volna megtudni, hogy a vizsgálathoz használt nem őshonos Bd törzset milyen óvintézkedéssel tartották a laboratórium falai között, és mi történt a kísérleti állatokkal. A válasz szerint a ki- és belépést szigorúan ellenőrizték, a laboratóriumban használt ruházatot minden használat után alaposan fertőtlenítették. A békákat pedig kíméletesen elpusztították. SZÖVÉNYI GERGELY: A Bd törzs honnan származott, és kereszteződött-e már más Bd törzsekkel? DREXLER TAMÁs: A törzs Spanyolországból származik, és antropogén hatások miatt terjedt el ott, és más törzsekkel már kereszteződött. SzÖVÉNYI GERGELY: Hazánkban él-e endemikus Bd törzs ill. mi lehet a következménye annak, ha a kozmopolita törzzsel találkozik? DREXLER TAMÁs: A hazai törzs kutatása folyamatban van. HORNUNG ERZSÉBET azt kérdezte, hogy a természetben mi a maximális Bdkoncentráció a fertőzés során. Előadó a pontos számértékre nem emlékszik, de állította, hogy a laboratóriumi fertőzés körülményei a lehető legrealisztikusabbak voltak. JÁNOSSY LÁsZLÓ elmondta, hogy gépjármüvek általi gázolások adatai alapján az elmúlt 12 évben csökkent mindkét fenti békafaj állománya, ami sok tényező eredménye (pl. fungicidek), és az időjárással sem látszik összefüggés - mindenesetre örömteli, hogy a Bd nem tartozik e tényezők közé. SzÖVÉNYI GERGELY felvetette, hogy mivel Spanyolországban tömegesen pusztul a barna varangy ottani egyik rokonfaja (Bufo spinosus), ezért a két varangyfajt öszszehasonlító vizsgálatoknak volna érdemes alávetni, föleg a kémiai különbségek kutatására koncentrálva. Az előadó elmondta, hogy fertőzéses összehasonlító kísérletet végeztek már e két $B u f o$ fajon, amelyböl kiderült, hogy a $B$. spinosus mortalitás sokkal magasabb, mint a $B$. bufo fajé, továbbá az előbbi faj már ebihalkorban erősen fertőződik.

4. KÁsler Andrea, Tóth Zsolt és HoRnUng ERzsébet: Városi erdöfoltok biodiverzitás-megtartó szerepe.

Szerzők szárazföldi ászkarákokat és ikerszelvényeseket vontak be a vizsgálatba. Az urbanizáció következtében az élőhelyek fragmentálódnak és változatosságuk csökken; az ezeket benépesítő fajok homogenizálódnak; kozmopolita, idegenhonos fajok jelennek meg. A lebontó szervezetek a városi élőhelyeken is fontos, de még alig kutatott szerepet játszanak. Szerzők kutatásának célja volt, hogy a főváros budai oldala fás területeinek ászka- és ikerszelvényes-faunáját felmérjék, és ebből az élőhelyek természetességi állapotára következtessenek. Feltételezték, hogy az egyre kevésbé zavart élőhelyeken fokozatosan csökken a kozmopolita, behurcolt és szünantróp fajok aránya. 23 mintaterületet vizsgáltak 2016 májusában és októberében, minden mintaterületen 60-60 percen át egyeléssel gyüjtöttek. Az anyagot faji szinten határozták. A területeket jellemezték a holtfa és az avar mennyiségével, valamint a lombkorona zártságával is, ezenkívül mérték a talaj pH-ját és egyéb kémiai paramétereket is. Továbbá természetességi és urbanizációs (beépítettségi) indexeket is bevon- 
tak a jellemzéshez. Eredményeik alapján a helyszínek folyamatos átmenetet mutattak az alig és a jelentősen urbanizált állapot között. A kevésbé beépített területeken több avart és holtfát találtak, valamint zártabb volt a lombkoronaszint, mint a jobban beépített helyeken. Összesen 13 ászka- és 14 ikerszelvényes fajt fogtak. Utóbbiak diverzitására a holtfa menynyisége szignifikáns mértékben pozitívan hatott, míg az ászkákra a holtfa mennyisége és a talaj kötöttségének mértéke is szignifikáns hatással volt. A legtermészetesebb területeken csak őshonos ászkafajok fordultak elő, ám az ikerszelvényesek nem mutattak ilyen összefüggést. Következtetéseik szerint a városi élőhelyek menedéket jelentenek az őshonos-, és egyúttal megtelepedési lehetőséget a kozmopolita fajoknak. Kívánatos lenne, ha nem távolítanák el a parkokból az összes avart, ill. holtfát. Elmondható az is, hogy a vizsgált csoportok megfelelően jellemzik egy terület természetességét. NAGY PÉTER megkérdezte, hogy szeretnék-e közölni az eredményeket. Az igenlő válasz után kifejtette, hogy ez fontos volna, mert az illetékesek felé meg lehetne indokolni a parkok kezelésének megváltoztatását egy természetközelibb parkgondozás irányába. Legalább bemutató jelleggel, "erdei iskola" gyanánt hagyhatnának meg holtfát. JÁNOSSY LÁSZLÓ hozzátette, hogy Bécsben, javaslatok hatására meghagyták az avart a parkokban, és hamarosan visszaköltöztek régóta eltünt madarak pl. fülemüle. Ezzel éles kontrasztban áll egy Városmajor-beli tapasztalata: egyik bokorban szívesen tanyázott egy fülemüle, ám a következő évben azt a bokrot teljesen lenyírták.

\section{1. előadóülés, 2017. november 8-án}

Az előadóülést NAGY PÉTER elnök úr vezette le.

1. Bilicsi ERIKA és SALlai ÁGNes: Bemutatkozik az MTA Könyvtár és Információs Központ Szakinformatikai Osztálya.

1825-ben több gazdag nemes az Akadémia és a Ludoviceum létrehozására ajánlotta fel javai egy részét, pl. TELEKI JÓZSEF a 30 ezer kötetes családi könyvtár adományozásával megteremtette az Akadémia könyvtárának alapját. Tényleges működése 1830-ban kezdődött, már tudományos szakkönyvtárral. A könyvtári adatbázisok fejlődése a hordozó anyagának változásával érhető tetten: a kezdeti papíralapú után következett a mágnesszalag, majd a CD, a DVD, és most már az interneten érhetők el ezek az adatbázisok. Az informatikai föosztályt 1979-ben hozták létre, mely az ISI (Institute for Scientific Information) által létrehozott Science Citation Index adatbázist vette át. Az üzembe helyezés az ISI szakembereinek segítségével történt, két év múlva indult el a könyvtár fizetős szolgáltatása, mely magában foglalta a tartalom- és témafigyelést (ezek az internet megjelenésével kikoptak), a publikációs jegyzékek nyilvántartását és az idézettség figyelését is. Ma a Web of Science rendszerre alapul az MTA adatbázisa, mely interdiszciplináris; természet-, társadalom-, valamint bölcsészettudományi-művészeti területtel. Az adatbázisban keresve egy közleményhez megjeleníti annak teljes szövegét (amennyiben feltöltötték), a szerzők és a folyóirat adatait és az idézettséget. Egyéb hasznos keresőfelületek a Scopus és a MATARKA. Az Akadémia repozitóriuma a REAL-gyüjteménycsalád, amely tudományos anyagokat archivál és tesz hozzáférhetővé. Nemcsak folyóirat-cikkeket (REAL-J), hanem akár kutatási adatokat is tárol. Ha a feltöltő megadja email címét, akkor személyesen el lehet tőle kérni a 
közleményt. Ennek föleg azért van jelentősége, mert a könyvtárprogram felismeri, hogy az adott folyóirat hozzájárul-e cikkeinek ingyenes terjesztéséhez, és eszerint engedi vagy tiltja a munkák letöltését. Az előadó bemutatta, hogyan lehet keresésre használni az oldalt. Az utóbbi időben jelentős az Open Access mozgalom, melynek fő célja az idézettség növelése. A nyilvánossá tétel háromféle úton lehetséges: az "arany" kategóriában a folyóirat biztosít nyílt hozzáférést, a "zöld" út az önarchiválás pl. a REAL-ban, melyre mindenkit buzdít az előadó, végül a "szürke" út a nem-könyvtári adatbázisba történő feltöltés, ahol sem a szerzői jog, sem a hosszútávú megőrzés nem garantált; ilyen - minden kényelme ellenére - a ResearchGate is. Az előadás záró részében egyéb fontos internetes adatbázisokról és a bennük történő keresést könnyítő azonosítókról volt szó. A DOAJ (Directory of Open Access Journals) adatbázis nagy előnye, hogy a folyóiratoknak utána lehet nézni, így a "parazita" lapok kiszürhetők. Az ORCID egy szerzői azonosító kód, személyhez kapcsolt (névváltoztatás stb. nincs hatással rá), megkönnyíti az adatbázisok számára az adatok felvételét. Ingyenesen kérhetö. Hasonló jellegü, de szakcikkekhez kapcsolható azonosító a DOI, mely biztosítja a cikkek örök elérhetőségét (pl. honlapcím megváltozása esetén is). A cikkekhez közölt mellékletek kiváltására szolgál az OpenData, ahová ezen adatok tölthetők fel. Már az MTMT-be (Magyar Tudományos Művek Tára) is felvihetők nyers adatok. Az előadás azzal zárult, hogy a szerzők felajánlották, hogy az előadás anyaga terjeszthető a Magyar Biológiai Társaság levelezőlistáján (még nem történt meg). NAGY PÉTER, amellett, hogy az előadás hasznosságát kiemelte, érdeklődött, hogy az MTMT új verziója elindul-e jövő év közepén. A válaszból kiderült, hogy az indulás határozatlan időre el lett halasztva, jövő nyár előtt semmiképp sem várható.

2. ZSEBÖK SÁNDOR, STEFAn GREIF, DANIELA SCHMIEDER és BJÖRN M. SIEMERS: Denevérek érzékelési csapdái: az akusztikus tükrök.

Az állatvilágban az érzékelési csapdák több formája ismert, legismertebbek a mesterséges fény, ill. a vízéhez hasonló polarizációs mintázatú mesterséges felületek. Az ilyen csapdák lényege, hogy az állatokat olyan abnormális viselkedésre késztetik, mely számukra nem előnyös. A denevérekre térve Előadó elmondta, hogy ma már 1200-nál több fajuk ismert, melyek mindegyike ekholokációval tájékozódik. A vízfelszín számukra akusztikus tükör: a kibocsátó példánytól távolodó irányba veri vissza az ultrahang nagy részét, a denevérhez csak a felszínre merőlegesen kibocsátott hanghullámok jutnak vissza. Ez utóbbiak intenzitásától állapítják meg az állatok a vízfelszíntől vett távolságukat (magasságukat). Ugyanakkor nagyméretü sík tárgyakat is vízfelszínként azonosítanak, inni próbálnak róluk - ez genetikailag kódolt, még az igazi vízfelszínt sosem érzékelt példányok is így viselkednek. A függőleges akusztikus tükör hasonló módon veri vissza a hanghullámokat, ám Szerzők kevés erre vonatkozó adatot találtak az irodalomban. Ezért kísérletet állítottak össze: egy szoba padlójára homokot szórtak, falát filccel vonták be (e felületek már túl érdesek ahhoz, hogy akusztikus tükrök legyenek), és a szoba közepét elkerítették úgy, hogy a denevérek csak a falak mentén repülhessenek. A szobába akusztikustükör-tulajdonságú lapokat helyeztek vízszintes és függőleges állásban, szomjas denevért engedtek a helyiségbe, és több kamerán át figyelték, mi történik. Ilyen felvételeket az ülés közönségének is bemutattak. Azt tapasztalták, hogy a vízszintes tükörről többször is inni próbáltak az egyedek, míg a függőleges felületeknek nemegyszer nekirepültek. Az ütközések előtt általában korrigálni próbáltak (későn vették észre), de néha semmiféle manővert nem hajtottak végre (egyáltalán nem vették észre). Semmi másnak nem ütköztek. Minél hegyesebb szögben ("laposab- 
ban") érkezett a denevér, annál nagyobb eséllyel ütközött, míg a merőlegesen közelítő egyedek mindig időben észrevették az akusztikus tükröt, és elkerülték az ütközést. Terepen is végeztek kísérletet: a Szársomlyó (Villányi-hegység) egyik barlangjának szája közelébe rugalmas lapokat állítottak fel, és ott is tapasztaltak ütközéseket. Más kutatók legalább 3 fajnál figyeltek meg ilyen ütközéseket, így mindezekből megállapítható, hogy a függőleges sík felületek potenciálisan veszélyesek a denevérek számára, kolóniáik közelében nem ajánlatos ilyenek kihelyezése (akár nagyobb ismertető táblák pl. tanösvényen). Előadó épületnek ütköző denevérekröl készített videót is lejátszott. NAGY PÉTER megkérdezte, hogy üvegfelületek kezelésével, "érdesítésével" javítható-e a helyzet. Előadó szerint igen, ezt kutatni kellene, azonban elöbb a tényleges veszély mértékét kellene feltárni. Ezután SzÖVÉNYI GERGELY beszámolt arról, hogy éppen most kaptak egy sérült denevért. Érdeklődött, hogy ilyen ütközéstöl sérülhetett-e az állat. Előadó szerint elképzelhető, ám rengeteg más oka is lehet. SZINETÁR CSABA említette, hogy publikált megfigyelések szólnak arról, hogy szélerőmüvek környékén hazánkban sok elpusztult denevért lehet találni, a hozzászóló szerint talán a rotorlapátok tükörhatása miatt. Előadó véleménye alapján sokkal inkább a turbulencia okozza az elhullást: olyan erös légörvények keletkeznek a rotorlapátok nyomán, amelyek végzetes belső sérülést okoznak az állatoknak. SzÖVÉNYI GERGELY felvetette, hogy e hatást súlyosbíthatja az, hogy egy ilyen szélerőmű ultrahangképe egy hatalmas lombos fára hasonlíthat, mely igen vonzó lehet a denevérek számára.

3. Horváth Gergely, BereczKi Judit, URSZÁn TAMÁs, BALÁzs Gergely, GARAMSZEGI LÁSZLÓ és HERCZEG GÁBOR: Az ászkaszemélyiség környezetfüggösége.

A viselkedési konzisztencia (állati személyiség) bizonyos viselkedésben fennálló egyedi eltérés, amely időben és élethelyzetekben konzisztens. Már sokféle taxonban vizsgálták korábban. A tudományterület egyik nagy közelmúltbeli felfedezése, hogy az egyeden belüli viselkedési variancia is lehet adaptív. Az utóbbi években igen széles statisztikai eszköztár jött létre a tudományterület számára. A viselkedési konzisztenciát úgy mérik, hogy minél több állat viselkedését minél többször megfigyelik, minden egyedre kiszámítják a viselkedési változó átlagos értékét, melyből az egyedek viselkedési típusát meg lehet állapítani. A viselkedési variancia a viselkedési plaszticitásból és -prediktabilitásból áll össze (előbbi környezet-indukálta változás, utóbbi stabil környezetben mérendö). Szerzők a közönséges gömbászkát (Armadillidium vulgare) választották kísérleti alanynak, mert egyszerüen hozzáférhető és tartható nagy számban, és kockázatvállalásuk könnyen mérhető az egyedek összegömbölyödésével. 25 egyednél mérték, hogy szimulált támadás (kézbevétel) után mennyi idő múlva egyenesednek ki. Minden egyedet harmincszor saját lakódobozába, harmincszor idegen helyre engedtek el kézbevétel után. A lehetséges állapotváltozók közül az ivart, testméretet és Wolbachia általi fertőzöttséget vették figyelembe. Ez utóbbi intracelluláris parazita baktérium, melyet csak nőstények hordoznak, és szaporodással adódik át. Ászkákban a feminizáció és a citoplazmatikus inkompetencia (csak fertőzött nőstény szaporodhat) tüneteit okozza. Más ízeltlábúakban az előzőeken kívül indukálhat szüznemzést, és elpusztíthatja a hím utódokat. Az ászkákban két törzsük található: egyikük feminizál, nem fertőz és direkt negatív hatása van pl. az immunrendszer pusztítása miatt; a másik citoplazmatikus inkompetenciát okoz, de nincs direkt negatív hatása. Szerzők eredményül azt kapták, hogy a Wolbachia-fertőzésben szenvedő egyedek később egyenesedtek ki, "gyávábbak" voltak, mint a fertőzésmentes példányok, és feltehetően a sérült immunrendszerük miatt vállaltak kevesebb kockázatot; a nagyobb egyedek gyávábbak voltak a 
kisebbeknél, ők vonzóbbak lehetnek a ragadozók számára; a környezet hatása abban nyilvánult meg, hogy az idegen helyen később bújtak ki, mint saját lakódobozukban; az idegen helyen jobban változott a viselkedés, az egyedek egyre gyávábbak lettek, és a nagyobb egyedek plasztikusabbak voltak, mint a kisebbek - itt az a feltételezés, hogy a kevésbé kockázatvállaló egyed plasztikusabb; és az ismerős helyen lévő nőstényeknek viselkedtek a leginkább prediktálható módon. A ragadozók zsákmányukat annak kiszámítható viselkedése alapján keresik. Szerzők azt a következtetést vonták le, hogy minden választott viselkedési változó releváns komponens. HORNUNG ERZSÉBET azt kérdezte, hogy nézték-e az egyedek szaporodási állapotát. Az előadó nemleges válasza után tanácsolta, hogy érdemes lenne. Előadó szerint egyetlen egyed petézett a kísérlet során. Hozzászóló másik kérdése arra vonatkozott, hogy mi a különbség saját és idegen környezet között. Előadó válasza: az első a saját lakódoboza, élőhelyéről származó avarral, míg az idegen környezet egy sima felszínủ müanyag lap volt. HORNUNG ERZSÉBET felhívta a figyelmet, hogy akkor az elnevezés nem szerencsés, amit az előadó elismert. NAGY PÉTER felvetette, hogy talán elég lett volna enyhébb behatással (pl. piszkálással) vizsgálni. Előadó válasza szerint a kézbevétel gerinces ragadozó támadását hivatott modellezni, és mindenképp el akarták érni, hogy öszszegömbölyödjenek az állatok.

\section{SZINETÁR CsABA: Könnyübúvárként Szudánban.}

Előadó fényképekkel gazdagon illusztrált útibeszámolót tartott. A Vörös-tenger a hozzánk legközelebb lévő trópusi tenger, ám egyúttal a legszegényesebb is. Ennek ellenére jelentős búvárturizmusa van, mely elsősorban Egyiptomban, másodsorban Szudánban koncentrálódik. Annak ellenére így van, hogy ez utóbbi ország kalandosan, sok türelmet igényelve érhető csak el (repülővel dubai átszállásra kell készülni). Az ország vizeinek zoológiai feltárása 1949-ben kezdődött, olyan kutatók által, mint HANS és COUSTEAU. Ilyen elődök megléte az egyik feltétele a szudáni búvárkodásnak, további feltételek még egy jó csapat, egy biztonságos hajóval rendelkező búvárcég, a megértő család, valamint bizonyos oltások és anyagiak megléte. Érkezéskor Dubaiban homokvihar tombolt, ráadásul Szudánban sem a tervezett helyen szállt le a repülőgép. Nem tudtak azonnal a célállomásra (Port Szudán) repülni, Előadó madarak megfigyelésével töltötte el az időt. Végül megérkeztek, és öt nap alatt 19-szer merültek; egyik helyük Shaab Rumi volt, amelyet CoUSTEAU bázisául választott, és ma a világ tíz legjobb merülőhelye között van. Nappali merülésein többek között óriáskagyló, bohóchalak, kékpettyes rája, korallör hal, sok pörölycápa (20-50 fös csapatok), cserepes teknős és óriás papagájhal került szeme elé. Utóbbi faj fejével faltörőkosszerüen darabokat tör le a korallról, ezzel táplálkozik. Az ütközések hangja jól hallható a víz alatt. Éjszaka kígyókarú csillagot, tengeri liliomot, elektromos ráját, óriás murénát, doktorhalat, tüzhalat, töviskoronás csillagot, gömbhalat, emberre is halálos döfésủ térképkúpcsigát és óriás tengeri uborkát figyeltek meg a sok más élőlény közt. Hajójukra madarak szálltak le, és néha repülőhalak is. Elöadó éjszaka planktont gyüjtött, ekkor találkozott tengeri molnárpoloskával (nagy egyedszámban) és üvegangolnával. Az előadást Előadó által készített 5 perc $17 \mathrm{mp}$ hosszú, víz alatti videofelvételekböl összeállított film zárta. GÖRFÖL TAMÁS azt kérdezte, milyen géppel fényképezett a szerző a víz alatt. SzINETÁr CSABA Nikon típusú fényképezőgépet használt, a filmet egy középkategóriás Olympus videokamerával és GoPro-val készítette. 